\title{
ALGORITHM FOR DESIGNING OF SPEED CHANGE CONTROL DEVICES THROUGH A GEAR DIFFERENTIAL WITH A CLOSED- LOOP HYDRAULIC SYSTEM
}

\author{
Oleh Strilets $^{1}$; Volodymyr Malashchenko²; Viacheslav Pasika ${ }^{2}$ \\ ${ }^{1}$ National University of Water and Environmental Engineering, Rivne, Ukraine \\ ${ }^{2}$ Lviv Polytechnic National University, Lviv, Ukraine
}

\begin{abstract}
Summary. The algorithm of practical application of researches results of speed changes management devices with a gear differential and the stopper of rotational movement in the form of the closed-loop hydraulic system has been described. An example is a single-stage single-row gear differential, when the driving link is a sun gear, driven is a ring gear, and the control link is a carrier. For such a device, the order of execution of in design steps has been described. The described execution procedure of speed change devices designing will be valid for all kinematic schemes of single-and multistage gear differentials with stoppers of rotational movement in the form of the closed-loop hydraulic systems with control through carriers.
\end{abstract}

Key words: speed change control device, gear differential, closed-loop hydraulic system, sun gear, ring gear, carrier, planet.

Statement of the problem. In mechanical drives of machines and various manufacturing units there is a need to control changes in the speed of their executive mechanisms to ensure technological processes. Currently, devices with stepped and stepless speed control, respectively, using stepped and stepless gearboxes, which have either simple and complex gear transmissions, or chain, or belt and friction variators are widely used. The main disadvantages of the existing stepped speed control are the complexity of the design, high material consumption, the automation process complexity, the emergence of dynamic loads during transitions from one speed to another. In te same time, traditional stepless control drawbacks are intensive wear of parts due to the use of friction joints. This significantly reduces the durability and reliability of drive parts and machines in general. Therefore, based on the review and analysis of existing speed change devices [1, 2], it is concluded that the urgent scientific and technical task is to develop and study new combined devices for stepless control of the speed change process consisting of single- and multistage gear differentials with rotational motion stoppers in the form of closed-loop hydraulic systems [3-8] installed on the control links - sun gears, ring gears or carriers, instead of locking friction belt, pad and disc brakes and couplings.

Analysis of the available investigations. To compile the algorithm for designing the devices for speed change through gear differentials with a rotational motion stopper in the form of a closed-loop hydraulic system, scientific works of authors [1-5] and other scientists [6-15] together with the classical technical literature [16-21] are recommended for use in the algorithm for determining kinematic, power and energy parameters, as well as dimensions in their design.

In [1-5] the known methods and devices for speed control have been widely considered, which have many disadvantages and the conclusion have been made about the development of a new method, more rational - through gear differentials with 
rotary stoppers in the form of closed-loop hydraulic systems instead of friction brakes and clutches. The structure of speed change devices and their components have been described and the possibility of speed change control have been substantiated, if we take, for example, the leading link - a sun gear, driven - ring gear, and the speed control link - carrier. Kinematic studies have been given related to the control of speed changes through the carrier using computer simulation of analytical expressions and obtaining graphical relationships between the speeds of the gear differential. Energy studies have been performed by determining the efficiency (efficiency coefficient), using the method of potential power to evaluate the device speed change in terms of power loss and possible self-braking. The structure and principle of operation of the rotational motion stopper in the form of a closed-loop hydraulic system have been described. The choice of the gear pump with external gearing for the closed-loop hydraulic system has been reasoned. Based on classical analytical kinematic and force dependences with the use of computer modeling analytical expressions and graphical dependences have been obtained, a dynamic model has been built and thermal calculation has been performed. When designing a closed-loop hydraulic system and optimizing its size, it has been proposed to initially perform 3D modeling of its components. Dynamic models have been developed for processes in devices for change of speed by means of gear differential to choose the necessary closed-loop hydraulic system in case of the carrier control link when one shaft of gear differential is driven by the electric motor and the second (hydraulic motor) is used to obtain the necessary law of motion on the driven link. To model the motion of a mechanical system (gear differential plus carrier drive), it is recommended to use, in a formalized form, the Lagrange equation of the second kind, which includes the kinetic energy of the speed change device, consolidated moments and torques. In order to optimize the size of the speed change devices at the beginning it has been recommended to perform 3D modeling, and then choose the best option and start making technical documentation.

In [6-12] some works of foreign scientists on research and design of differential transmissions have been resulted. In particular, the design of a planetary transmission with a high gear ratio have been considered. Studies held of the effect of changing the shape of the tooth profile on the dynamics of gears with moving axes. A nonlinear dynamic analysis of closed differential gears has been performed. Some theoretical and experimental methods for determining the energy efficiency of the considered gears have been described. Works [1315] contain a description of the structure and study of brakes of various types used in the design of continuously variable transmissions.

The considered scientific sources [1-15] together with the classical [16-21] scientific sources related to this topic are proposed for use in the algorithm for determining the kinematic, energy and power parameters and dimensions in the design of devices for speed change through the gear differential with rotational motion stopper in the form of a closedloop hydraulic system. Creating an algorithm for designing such devices will reduce the designing time.

The objective of the work is to give an example of the procedure for performing practical calculations of devices for speed changes controlling through single- and multistage gear differentials with rotational motion stoppers in the form of closed-loop hydraulic systems in the case where the leading link is a sun gear, driven - ring gear, and the control link is the carrier, using the results and extend this algorithm to all efficient schemes - with high efficiency.

Implementation of work. The main initial data for the design should be: power $P_{i n}, k W$ and angular velocity $\omega_{i n}, \mathrm{rad} / \mathrm{s}$ of the drive shaft, the gear ratio between the driving and driven shafts $u$ of the speed change device and various technical and technological 
conditions. In addition, much data is selected or received during the calculations, based on the classic advice relating to the design stages, or obtained from studies of speed control devices through gear differentials with rotational motion stoppers in the form of closed-loop hydraulic systems. Fig. 1 shows the basic schemes of gear differentials taken from classical scientific sources [16].

Fig. 2 shows a device for changing speed through a single-stage single-row gear differential, which includes a sun gear 1 , planets set 2, ring gear 3, and the carrier 4, mounted in the housing 5 . The rotational motion stopper 6 is connected to the carrier shaft 4 by a gearing 7 , from [1].

Consider the case when the driving link is the sun gear, and the driven is the ring gear. The change in the speed of the driven link - the ring gear is carried out through the carrier. If we take the angular velocity of the driving link for $\omega_{1}=$ const, then by changing the speed of the carrier $\left(\omega_{4}=v a r\right)$ with the help of a rotational motion stopper, you can smoothly change the speed of the driven link - the ring gear $\left(\omega_{3}\right)$. We have the fact that the carrier through the gearing drives a hydraulic gear pump, which is part of a closed-loop hydraulic system and pumps fluid when the control valve is open. If the control valve is closed, then the hydraulic gear pump is stopped and, at the same time, the carrier is stopped $\left(\omega_{4}=0\right)$. Thus, depending on the capacity of the shut-off valve, the speed of the carrier $\left(\omega_{4}\right)$ varies from $\omega_{4 \max }$ to zero and, thus, the speed of the epicycle $\left(\omega_{3}\right)$ changes.
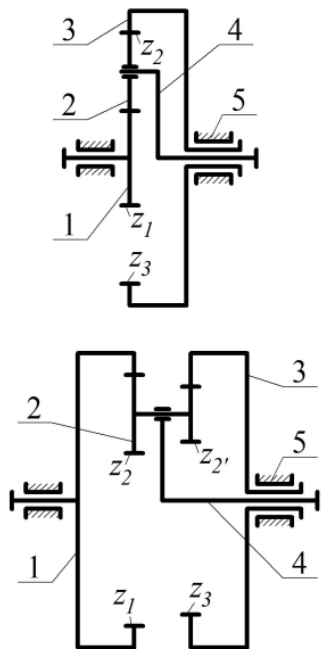

Figure 1. Basic schemes of gear differentials

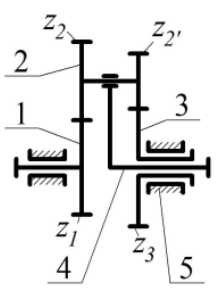

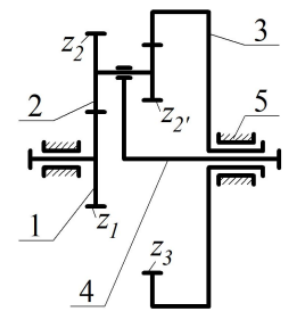

Figure 2. Scheme of a gear differential with control through the carrier

For the selected scheme of gear differential, the relationship between velocities is described by the expression from [2]

$$
\omega_{3}=\frac{\omega_{4}\left(1+u_{13}^{(4)}\right)-\omega_{1}}{u_{13}^{(4)}}
$$

or is given by graphic dependences shown in fig. 3, obtained by computer programming of expression (1). 


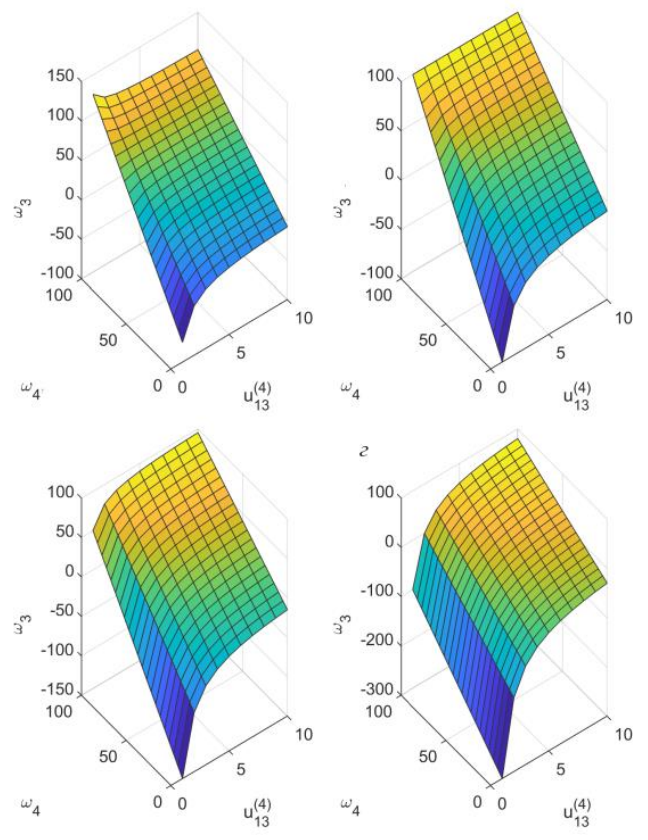

Figure 3. Graphic dependencie

$$
\omega_{3}=f\left(\omega_{1}, \omega_{4}, u_{13}^{(4)}\right)
$$
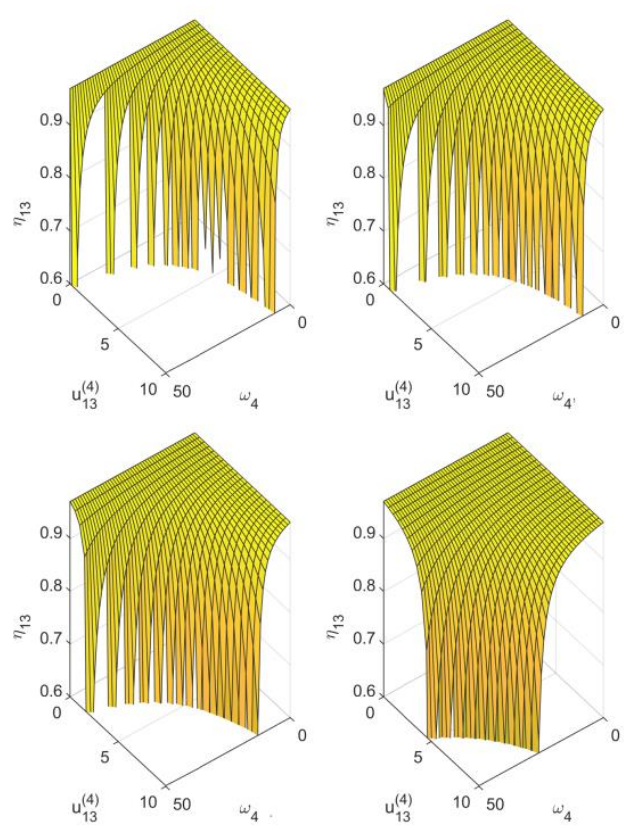

Figure 4. Graphic dependencies

$$
\eta_{13}=f\left(\omega_{1}, \omega_{4}, u_{13}^{(4)}\right)
$$

The energy efficiency of the speed change control device through the carrier of the gear differential is evaluated by the efficiency taken from [3],

$$
\eta_{13}=\frac{\left[\omega_{1}-\omega_{4}\left(1+u_{13}^{(4)}\right)\right] \eta_{13}^{(4)}}{\omega_{1}-\omega_{4}\left(1+u_{13} \eta_{13}^{(4)}\right)}
$$

or graphical dependences shown in Fig. 4, obtained by computer programming of (2).

Next, proceed to the synthesis of the gear differential to determine the number of teeth of the sun gear $z_{1}$, planets $z_{2}$ and ring gear $z_{3}$ and the number of plavets $k$ using classical advice, for example, [20] or other authors, for which equations are made to test conditions:

- given gear ratio:

$$
\frac{z_{3}}{z_{1}}=u_{13}^{(4)}
$$

- coaxiality of the solar gear and epicycle:

$$
z_{3}-z_{1}=2 z_{2}
$$

- assembly:

$$
z_{1}+z_{3}=k A
$$

where $A$ - arbitrary integer; 
- neighborhood:

$$
\sin \frac{\pi}{k}>\frac{z_{2}+2}{z_{1}+z_{2}}
$$

Equations (1-3) and inequality (4) are solved by selecting $z_{1}, z_{2} z_{3}$ and $k$, as indicated in the literature on the theory of mechanisms and machines, for example, [20].

The kinematic parameters are specified using the results of kinematic research $[1,2]$ and energy capabilities using the results of research [3] of the future speed change device

Then we determine the torques on the shafts of the gear differential according to [17]. When the power and angular velocity on the drive shaft are known, you can determine its torque from the expression

$$
T_{i n}=\frac{10^{3} P_{i n}}{\omega_{i n}} .
$$

Knowing the torque of one shaft in the gear differential, you can determine the required others. For our case it will look like this:

$$
T_{1}=T_{i n} ; T_{2}=-T_{1} u_{12} \eta_{12} ; T_{3}=-T_{1} u_{13}^{(4)} \eta_{13} ; T_{4}=-T_{1}\left(1-u_{13}^{(4)} \eta_{13}\right) .
$$

Next, we perform preliminary calculations for the strength of the parts of the gear differential. Here determine the geometric dimensions of the gears, shafts and carrier, which will be used in the dynamic model of the speed changes control device. Calculations are performed by typical methods, as for simple transmissions - with fixed axes. The wheelbase is found using the expression for the condition of contact strength for straight gears:

$$
a_{w \min }=450(u \pm 1) \sqrt[3]{\frac{K_{H} T_{2}}{\psi_{a} u_{23}^{2}\left[\sigma_{H}\right]^{2}}},
$$

where $u$ is the gear ratio; $T_{2}$ - torque; $K_{H}$ - load factor; $\psi_{a}$ - gear width ratio; $\left[\sigma_{H}\right]$ - permissible contact stresses for tooth materials. The values included in expression (9) are selected from the reference literature according to the recommendations of, for example, [17] or other authors.

The gear modulus is then determined as

$$
m_{n}=\frac{2 a_{w m s n}}{z_{1}+z_{2}}=\frac{2 a_{w m s n}}{z_{3}-z_{2}}
$$

The obtained value of the gear module is rounded to the standard value and all geometric dimensions of gears and planets are determined.

Next, the minimum diameters of the shafts are determined from the condition of torsional strength, taking into account that they can be either solid or hollow

$$
d_{\min }=\sqrt[3]{\frac{10^{3} T_{i}}{0,2\left(1-\xi^{4}\right)\left[\tau_{k}\right]}}
$$


where $\xi=d_{0} / d_{\min }$ is the coefficient that characterizes the annular cross section of the shaft; $\left[\tau_{k}\right]$ - permissible torsional stresses. Next, choose bearings as shaft and planet supports, other components. Calculations are performed by methods given in the classical textbooks, for example, [17], or other authors.

Then proceed to the calculations of the components of the rotational movement stopper in the form of a closed-loop hydraulic system and its drive from the control link - the carrier, using the advice of research [4] and classical advice on this issue [18]. In fig. 5. the scheme and model of rotational movement stopper in the form of the closed-loop hydraulic system is shown. Using the kinematic, power and energy dependences in a closed-loop hydraulic system of a mechanical drive according to the power from the catalog [19] choose the hydraulic pump $H W$, which most rationally corresponds to the application in this speed changing device. Focusing on the conditional diameters of the suction and discharge holes of the pump, we accept pipes with the same holes diameters, choose a revers valve, control valve and other components of a closed-loop hydraulic system and its drive. The drive of the hydraulic pump is usually made in the form of a cylindrical gear, the geometric dimensions of the gears are determined as recommended by [18], or other authors. The structure of the rotary stop is widely described in $[1]$.
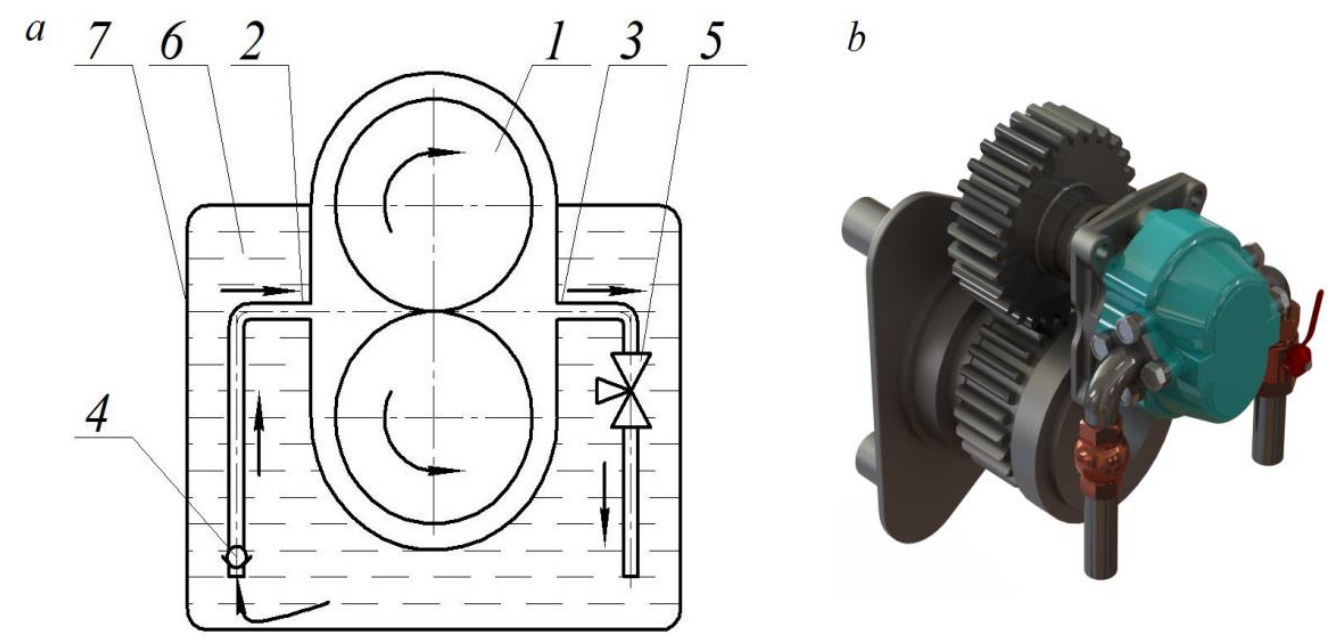

Figure 5. Scheme of stopper of rotational motion $(a)$ and 3D model with drive $(b)$

Next, for the dynamic model analysis for obtained final expressions of the torques from inertia of the driving and driven links $[5,19]$ we take and determine the values that they include:

$$
M_{i 1}=\frac{M_{s 3} J_{13}-M_{s 1} J_{33}}{J_{13}-\sqrt{J_{33} J_{11}}} ; M_{i 3}=\frac{M_{s 3} J_{11}-M_{s 1} J_{13}}{\sqrt{J_{33} J_{11}}-J_{13}},
$$

where:

$$
J_{11}=J_{1}+\frac{k J_{2}}{\left(u_{34}^{(1)}\right)^{2}}\left(u_{21}^{(4)} u_{34}^{(1)}-u_{31}^{(4)} u_{24}^{(1)}\right)^{2}+\frac{k m_{2} r_{C}^{2}+J_{4}+J_{7}+J_{7^{\prime}}}{\left(u_{34}^{(1)}\right)^{2}}\left(u_{31}^{(4)}\right)^{2} ;
$$




$$
\begin{gathered}
J_{13}=\frac{2 k J_{2}}{\left(u_{34}^{(1)}\right)^{2}}\left(u_{21}^{(4)} u_{34}^{(1)}-u_{31}^{(4)} u_{24}^{(1)}\right) u_{24}^{(1)}+\frac{k m_{2} r_{C}^{2}+J_{4}+J_{7}+J_{7^{\prime}}}{\left(u_{34}^{(1)}\right)^{2}} u_{31}^{(4)} ; \\
J_{33}=\frac{k J_{2}}{\left(u_{34}^{(1)}\right)^{2}}\left(u_{24}^{(1)}\right)^{2}+\frac{k m_{2} r_{C}^{2}+J_{4}+J_{7}+J_{7^{\prime}}}{\left(u_{34}^{(1)}\right)^{2}}+J_{3}
\end{gathered}
$$

gear ratios:

$$
\begin{aligned}
& u_{21}^{(4)}=-\frac{z_{1}}{z_{2}} ; u_{31}^{(4)}=-\frac{z_{1}}{z_{3}} ; u_{24}^{(1)}=1-u_{21}^{(4)}=1+\frac{z_{1}}{z_{2}} ; u_{34}^{(1)}=1-u_{31}^{(4)}=1+\frac{z_{1}}{z_{3}} ; \\
& u_{7^{\prime} 7}^{(1)}=-\frac{z_{7}^{\prime}}{z_{7}} ;
\end{aligned}
$$

consolidated torques:

$$
M_{s 1}=M_{1}+M_{7} u_{71}^{(4)}, M_{s 3}=-M_{3}+M_{3} u_{77}^{(1)} .
$$

Here in expressions (13) we have: $J_{i}$ and $m_{2}$-dynamic moments of inertia of links with respect to the centers of mass and mass of the planet; $k$ is the number of planets; $v_{C}=\omega_{4} r_{4}$ - circular speed of the axis of rotation of the planet, $r_{4}$ - the radius of rotation of the carrier. This radius is equal to the sum of the initial radii of the sun gear and the planet $r_{4}=0,5\left(d_{W_{1}}+d_{W_{2}}\right)$. Parameters with the corresponding designations relating to components of the speed change device correspond to the scheme shown in fig. 2. The dynamic moments of inertia of cylindrical gears are defined as $J_{i}=0,5 m_{i} r_{i}^{2}$, where $m_{i}$ and $r_{i}$ - respectively, the mass and radius of the gear. The consolidated moment $M_{s 1}$ is determined from the equality of powers of the moments of forces when carrier fixed, and the moment $M_{s 3}$ when sun gear fixed. The moment $M_{1}=M_{1}\left(\omega_{1}\right)$ is a function of the angular velocity of the sun gear, the moment of load change on the ring gear shaft $M_{3}=M_{3}(t)$ depends on time, and $M_{7^{\prime}}=M_{7^{\prime}}\left(v_{\text {fluid }}\right)$ depends on the fluid consumption of the hydraulic system.

The moment $M_{s 3}$ which is the moment of resistance and is applied to the driven link - ring gear, for this example, and is accepted from schemes of characteristic cases of loading change in the form of the torque $M$ of resistance of the executive mechanism shown in fig. 6: $a$ - the load changes periodically over a long period of time; $b$ - the magnitude of the shock load after a sharp increase remains unchanged for a long time; $c$ - the magnitude of the shock load after a sharp increase is maintained for a short time; $d$ - the actuator stops instantly due to significant overload.

In expressions (15) to determine the torques we have: $P$ - power; $p$ - pressure in a closed-loop hydraulic system; $q$ - the cost of the hydraulic pump per revolution of the shaft; gear ratio $u_{71}^{(4)}=u_{13}^{(4)} u_{7^{\prime} 7}$.

Next, determine the torque of all links of the gear differential and evaluate its operation in the speed change device. 

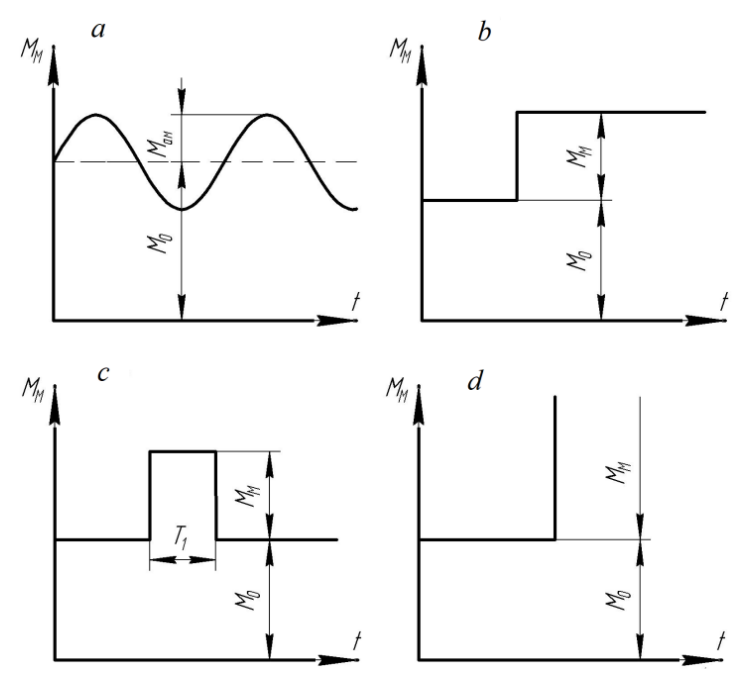

Figure 6. Graphs of torque change on the working mechanism shaft in Fig. 7.

And, finally, a 3D model of the device is designed according to the advice [21], shown

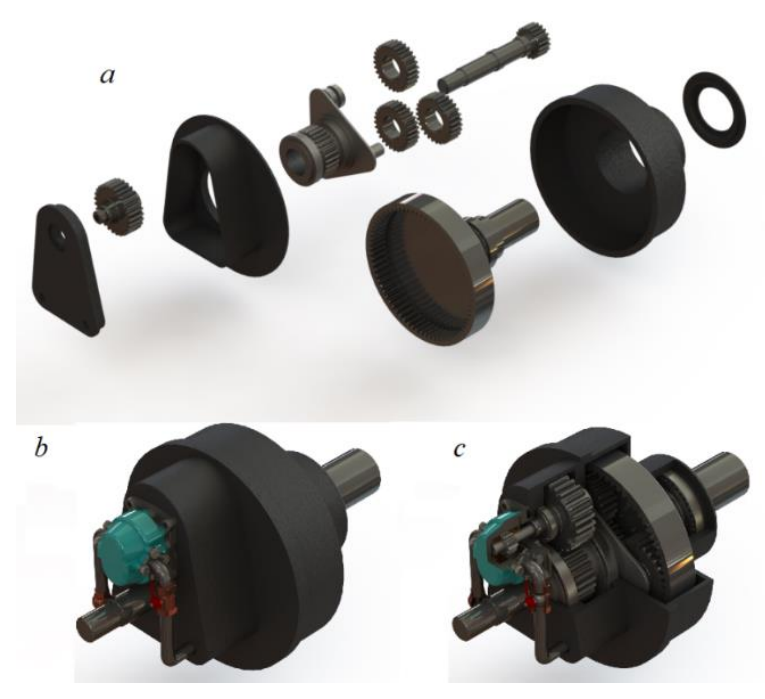

Figure 7. Models of parts and assembly of differential transmission with closed-loop hydraulic system control through the carrier: $b$ - without cut and $c$ - with cut

The 3D model is proposed to be implemented in order to optimize the size and placement of the components of the speed change device, because at the initial stage of design you can get a visual idea of differential transmissions with closed-loop hydraulic systems and use a computer to view them from anywhere; increase design accuracy; easy to edit three-dimensional models, i.e. make the necessary changes; achieve great savings in time and costs; get a large number of possible design solutions that need to be analyzed in detail and in depth and choose a rational one; on the basis of the created basic models of transfers it is possible to receive models of transfers with the different sizes. At the final choice of the optimum variant of model, after various specifications, start development of technical documentation of the device of change of speed by means of a gear differential and the stop of rotational movement in the form of the closed hydraulic system. The calculation steps are performed using computer programming. 
Algorithm for designing of speed change control devices through a gear differential with a closed-loop hydraulic system

Conclusions. This paper proposes a procedure for practical calculations and selection of parameters of the components of the speed change device on the example of a single-stage single-row gear differential, when the leading link is a sun gear, driven - ring gear, and speed control is carried out through the carrier using classical research and previous authors' results. The given example can be used, as algorithm, for calculations at designing of speed change devices with gear differentials and rotational movement stoppers in the form of the closed-loop hydraulic systems of any schemes and their work in the forward and revers directions. The proposed computer-aided design with simulation can be a significant addition to the existing and previously developed by the authors of theoretical methods for determining the rational dimensions of the drive elements of mechanisms and machines of various branches of engineering and an important basis for further research.

\section{References}

1. Malashchenko V. O., Strilets O. R., Strilets V. M. Novyy sposob besstupenchatogo izmeneniya skorosti pri pomoshchi zubchatykh differentsial'nykh peredach s zamknutoy gidrosistemoy. Mezhdunarodnyy inzhenernyy zhurnal "Privody i komponenty mashin". 2015. No. 4-5. P. 7-10. [In Russian].

2. Malashenko V., Strilets O., Strilets V. Method and device for speed change by the epicyclic gear train vith stepped-planet gear set, Research Works of AFIT. Warszawa: AFIT, 2016. Iss. 38. P. 13-19. DOI: https://doi.org/10.1515/afit-2016-0002

3. Malashenko V., Strilets O., Strilets V., Klysh S. Investigation of the energy effectiveness of multistage differential gears when the speed is changed by the carrier, Diagnostyka, Warchava, 2019. Vol. 20. No. 4. P. 57-64. DOI: https://doi.org/10.29354/diag/112397

4. Strilets O. R. Kinematychni, sylovi i enerhetychni zalezhnosti u zamknutiy hidrosystemi mekhanichnoho pryvodu. Visnyk NUVHP. Zbirnyk naukovykh prats. Seriya "Tekhnichni nauky". Rivne: NUVHP, 2020. Iss. 1 (89). P. 152-164. [In Ukrainian].

5. Strilets O., Malashchenko V., Strilets V. Dynamic model of a closed-loop hydraulic system for speed control through gear differential. Scientific Journal of TNTU. 2020. Vol. 98. No. 2. P. 91-98. DOI: https://doi.org/10.33108/visnyk_tntu2020.02.091

6. Pawar1 P. V., Kulkarni P. R. Design of two stage planetary gear train for high reduction ratio. Journal of Research in Engineering and Technology. eSAT Publishing House, Bangalore, India. 2015. Vol. 04. Iss. 06. P. 150-157. DOI: https://doi.org/10.15623/ijret.2015.0406025

7. Bahk C.-J., Parker R. G. Analytical investigation of tooth profile modification effects on planetary gear dynamics. Mechanism and Machine Theory. Elsevier. 2013. No. 70. P. 298-319. DOI: https://doi.org/10.1016/j.mechmachtheory.2013.07.018

8. Qilin Huang, Yong Wang, Zhipu Huo, Yudong Xie Nonlinear Dynamic Analysis and Optimization of Closed-Form Planetary Gear System. Mathematical Problems in Engineering. Vol. 2013. 2013. 12 p. DOI: https://doi.org/10.1155/2013/149046

9. Miguel Pleguezuelos, José I. Pedrero, Miryam B. Sánchez Analytical Expressions of the Efficiency of Standard and High Contact Ratio Involute Spur Gears. Mathematical Problems in Engineering. Vol. 2013. 2013. 14 p. DOI: https://doi.org/10.1155/2013/142849

10. Chen C. Power flow and efficiency analysis of epicyclic gear transmission with split power. Mechanism and Machine Theory. Vol. 59. 2013. P. 96-106. DOI: https://doi.org/10.1016/j.mechmachtheory.2012.09.004

11. Chao Chen, Jiabin Chen Efficiency analysis of two degrees of freedom epicyclic gear transmission and experimental. Mechanism and Machine Theory. Vol. 87. 2015. P. 115-130. DOI: https://doi.org/10.1016/j.mechmachtheory.2014.12.017

12. Laus L. P., Simas H., Martins D. Efficiency of gear trains determined using graph and screw. Mechanism and Machine Theory. Vol. 52. 2012. P. 296-325. DOI: https://doi.org/10.1016/j.mechmachtheory.2012.01.011

13. Michiel Plooij, Tom van der Hoeven, Gerard Dunning, Martijn Wisse Statially balanced brakes. Original Research Article Precision Engineering. Vol. 43. January 2016. P. 468-478. DOI: https://doi.org/10.1016/j.precisioneng.2015.09.013

14.Attia E. M., Elsodany N. M., El-Gamal H. A., Elgohari M. A. Teoretical and experimental study of magnetorheological fluid brake. Original Research Article Alexandria Engineering Journal. Vol. 56. Iss. 2. June 2017. P. 189-200. DOI: https://doi.org/10.1016/j.aej.2016.11.017

15.Kerem Karakoc, Afzal Suleman, Edvard J. Park Analytical modeling of eddy current brakes with the application of time varyieng magnetic fields. Original Research Article Applied Mathematical Modelling. Vol. 40. Iss. 2. 15 January 2016. P. 1168-1179. DOI: https://doi.org/10.1016/j.apm.2015.07.006

16. Kinytskyi Ia. T. Teoriya mekhanizmiv i mashyn: Pidruchnyk. NAN Ukrayiny. K.: "Naukova Dumka", 2002. 660 p. [In Ukrainian]. 
17. Andriyenko L. A., Baykov B. A., Ganulich I. K. i dr. Detali mashin / pod red. O. A. Ryakhovskogo. 2-ye izd., pererab. M.: Izd-vo MGTU im. N. Baumana, 2004. 520 p. [In Russian].

18. Yushkin V. V. Basics of calculating a volumetric hydraulic drive. Minsk: Vysh. shk., 1982. 93 p. [In Russian].

19. Gear pumps. Katalog. URL: https://www.hydrosila.com. [In Russian].

20. Barsov G. A., Bezmenova L. V., Grodzenskaya L. S. i dr. Teoriya ploskikh mekhanizmov i dinamika mashin / pod reaktsiyey A. V. Zheligovskogo, M.: Vysshaya shkola, 1961, 336 p. [In Russian].

21. Koziar M. M., Feshchuk Iu. V., Parfeniuk O. V. Kompiuterna hrafika. SolidWorks: Navchalnyi posibnyk, Kherson: OLDI-PLUS, 2018. 252 p. [In Ukrainian].

\section{Список використаної літератури}

1. Малащенко В. А., Стрилец О. Р., Стрелец В. Н. Новый способ бесступенчатого изменения скорости при помощи зубчатых дифференциальных передач с замкнутой гидросистемой. Международный инженерный журнал «Приводы и компоненты машин». 2015. № 4-5. С. 7-10.

2. Malashenko V., Strilets O., Strilets V. Method and device for speed change by the epicyclic gear train with stepped-planet gear set. Research Works of AFIT. Warszawa: AFIT, 2016. Iss. 38. P. 13-19. DOI: https://doi.org/10.1515/afit-2016-0002

3. Malashenko V., Strilets O., Strilets V., Klysh S. Investigation of the energy effectiveness of multistage differential gears when the speed is changed by the carrier. Diagnostyka. Warchava. 2019. Vol. 20 . № 4. P. 57-64. DOI: https://doi.org/10.29354/diag/112397

4. Стрілець О. Р. Кінематичні, силові і енергетичні залежності у замкнутій гідросистемі механічного приводу. Вісник НУВГП. Збірник наукових праць. Серія «Технічні науки». 2020. Вип. 1 (89). C. $152-164$.

5. Strilets O., Malashenko V., Strilets V. Dynamic model of a closed-loop hydraulic system for speed control through gear differential. Scientific Journal of TNTU. 2020. Vol. 98. No. 2. P. 91-98. DOI: https://doi.org/10.33108/visnyk_tntu2020.02.091

6. Pawar1 P. V., Kulkarni P. R. Design of two stage planetary gear train for high reduction ratio. International Journal of Research in Engineering and Technology. eSAT Publishing House, Bangalore, India. 2015 . Vol. 04. Iss. 06. P. 150-157. DOI: https://doi.org/10.15623/ijret.2015.0406025

7. Bahk C.-J., Parker R. G. Analytical investigation of tooth profile modification effects on planetary gear dynamics. Mechanism and Machine Theory, Elsevier. 2013. No. 70. P. $298-319$. DOI: https://doi.org/10.1016/j.mechmachtheory.2013.07.018

8. Qilin Huang, Yong Wang, Zhipu Huo, Yudong Xie Nonlinear Dynamic Analysis and Optimization of Closed-Form Planetary Gear System. Mathematical Problems in Engineering. Vol. 2013. 2013. 12 p. DOI: https://doi.org/10.1155/2013/149046

9. Miguel Pleguezuelos, José I. Pedrero, Miryam B. Sánchez Analytical Expressions of the Efficiency of Standard and High Contact Ratio Involute Spur Gears. Mathematical Problems in Engineering. Vol. 2013. 2013. 14 p. DOI: https://doi.org/10.1155/2013/142849

10. Chen C. Power flow and efficiency analysis of epicyclic gear transmission with split power. Mechanism and Machine Theory. Vol. 59. 2013. P. 96-106. DOI: https://doi.org/10.1016/j.mechmachtheory.2012.09.004

11. Chao Chen, Jiabin Chen Efficiency analysis of two degrees of freedom epicyclic gear ransmission and experimental. Mechanism and Machine Theory. Vol. 87. 2015. P. 115-130. DOI: https://doi.org/10.1016/j.mechmachtheory.2014.12.017

12. Laus L. P., Simas H., Martins D. Efficiency of gear trains determined using graph and screw. Mechanism and Machine Theory. Vol. 52. 2012. P. 296-325. DOI: https://doi.org/10.1016/j.mechmachtheory.2012.01.011

13. Michiel Plooij, Tom van der Hoeven, Gerard Dunning, Martijn Wisse Statially balanced brakes. Original Research Article Precision Engineering. Vol. 43. January 2016. P. 468-478. DOI: https://doi.org/10.1016/j.precisioneng.2015.09.013

14. Attia E. M., Elsodany N. M., El-Gamal H. A., Elgohari M. A. Teoretical and experimental study of magneto-rheological fluid brake. Original Research Article Alexandria Engineering Journal. Vol. 56. Iss. 2. June 2017. P. 189-200. DOI: https://doi.org/10.1016/j.aej.2016.11.017

15.Kerem Karakoc, Afzal Suleman, Edvard J. Park Analytical modeling of eddy current brakes with the application of time varyieng magnetic fields. Original Research Article Applied Mathematical Modelling. Vol. 40. Iss. 2. 15 January 2016. P. 1168-1179. DOI: https://doi.org/10.1016/j.apm.2015.07.006

16. Кіницький Я. Т. Теорія механізмів і машин: підручник. НАН України. К.: «Наукова Думка», 2002. $660 \mathrm{c.}$

17. Андриенко Л. А. и др. Детали машин / под ред. О. А. Ряховского. 2-е изд., перераб. М.: Изд-во МГТУ им. Н. Баумана, 2004. 520 с.

18. Юшкин В. В. Основы расчета объемного гидропривода. Мн: Выш. шк., 1982. 93 с.

19. Насосы шестеренные. Каталог. URL: https://www.hydrosila.com. 
Algorithm for designing of speed change control devices through a gear differential with a closed-loop hydraulic system

20.Барсов Г. А. и др. Теория плоских механизмов и динамика машин / под реакцией А.В. Желиговского. М.: Высшая школа, 1961. 336 с.

21. Козяр М. М., Фещук Ю. В., Парфенюк О. В. Комп’ютерна графіка. SolidWorks: навчальний посібник. Херсон: ОЛДІ-ПЛЮС, 2018. 252 с.

УДК 621.833.65

\title{
АЛГОРИТМ ПРОЕКТУВАННЯ ПРИСТРОЇВ КЕРУВАННЯ ЗМІНАМИ ШВИДКОСТІ ЧЕРЕЗ ВОДИЛО ЗУБЧАСТОГО ДИФЕРЕНЦІАЛА 3 ЗАМКНУТОЮ ГІДРОСИСТЕМОЮ
}

\section{Олег Стрілець ${ }^{1}$; Володимир Малащенко ${ }^{2}$; В'ячеслав Пасіка²}

\author{
${ }^{1}$ Начіональний університет водного господарства та \\ природокористування, Рівне, Україна \\ ${ }^{2}$ Національний університет «Львівська політехніка», Львів, Украӥна
}

Резюме. У механічних приводах машин $і$ різних засобах виробництва виникає необхідність керування змінами швидкості їх виконавчих механізмів. Для цього використовуються ступінчасті й безступінчасті коробки швидкостей. Відомі пристрої керування змінами швидкості мають багато недоліків, які негативно впливають на довговічність $і$ надійність компонентів приводів і машин у изілому. Основними недоліками існуючого ступінчастого керування швидкістю є складність конструкиї̈, велика матеріаломісткість, складність автоматизачії, виникнення динамічних навантажень під час переходів із однісї швидкості на іншу, а традииійного безступінчастого - інтенсивне спрацювання деталей внаслідок використання фрикційних зв'язків стрічкових, колодкових або дискових гальм та блокувальних фрикиійних муфт. Останнім часом у техніці широко застосовуються комбіновані пристрої зміни швидкості 3 зубчастими диференціалами і блокувальними фрикційними гальмами і муфтами. Це пов'язано з тим, щьо зубчастий диференціал володіє двома степенями вільності й в передачі руху приймає три ланки - сонячне зубчасте колесо, епіцикл і водило. Запропоновано, щзоб ланка для керування процесом зміни швидкості між ведучою і веденою ланками змінювала швидкість за допомогою зупинника обертального руху у вигляді замкнутої гідросистеми. Це дозволяє підвищчити зносостійкість таких пристроїв $і$ забезпечує плавність їх роботи. Для иьвого розроблені на рівні патентів на винаходи і корисні моделі ряд нових пристроїв керування змінами швидкості та проведені теоретично-комп 'ютерні кінематичні, енергетичні й силові дослідження. Метою даної роботи є приведення алгоритму застосування результатів досліджень при проектуванні пристроїв керування змінами швидкості. Відповідно до вихідних даних завдання на проектування пристрою керування змінами швидкості прочес починається з вибору кінематичної схеми зубчастого диферениіала, вибору ланки керування, обгрунтування його енергетичної ефективності коефіцієнтом корисної дї. Далі переходять до визначення числа зубиів сонячного зубчастого колеса, сателітів $і$ епіџиклу та числа сателітів, користуючись класичними порадами. Для цього складають три рівняння: заданого передавального відношення; співвісності сонячного зубчастого колеса $і$ епіциклу; складання й однієї нерівністі для числа сателітів - обмеження з умови сусідства. Уточняються кінематичні параметри користуючись результатами кінематичного дослідження. Після цього виконують попередні розрахунки на міцність деталей зубчастого диференціала. Тут визначають геометричні розміри зубчастих коліс, валів $i$ водила, які будуть використані в динамічній моделі пристрою для керування змінами швидкості. Розрахунки виконують методами, приведеними в деталях машин. Потім переходять до вибору шестерінчастого гідронасоса і компонентів зупинника обертального руху у вигляді замкнутої гідросистеми та його привода від ланки керування, користуючись порадами проведених досліджень. Далі на основі динамічної моделі та отримані остаточних виразів швидкостей або обертальних моментів інериії ведучої $і$ веденої ланок та використовуючи зв'язки між цими параметрами у зубчастому диференціалі можна проаналізувати його роботу. I, накінець, виконується 3D модель пристрою. При остаточному виборі оптимального варіанта, після різних уточнень, приступають до розроблення технічної документації пристрою зміни швидкості за допомого зубчастого диферениіала й зупинника обертального руху у вигляді замкнутої гідросистеми.

Ключові слова: пристрій для керування змінами швидкості, зубчастий диференціал, замкнута гідросистема, сонячне зубчасте колесо, епіцикл, водило, сателіт.

https://doi.org/10.33108/visnyk_tntu2021.01.138

Отримано 15.12.2020 